\title{
THE EFFECT OF FOLIAR NUTRITION WITH UREA, MOLYBDENUM, SUCROSE AND BENZYLADENINE ON YIELD AND SOME ORGANIC COMPOUNDS OF CARROT STORAGE ROOTS
}

\author{
Sylwester SMOLEŃ, Włodzimierz SADY \\ Department of Soil Cultivation and Fertilization of Horticultural Plants \\ University of Agriculture in Kraków \\ Al. 29 Listopada 54, 31-425 Kraków, Poland
}

Received: October 27, 2008; Accepted: January 20, 2010

\section{Summary}

The Kazan $F_{1}$ carrot was cultivated in years 2004-2005 in open-work containers sized $60 \times 40 \times 20 \mathrm{~cm}$ filled in with silt loam and located on the open field under shade providing fabric. The following combinations of experiments were arranged: (1) control - without foliar nutrition, and foliar nutrition with: (2) urea, (3) solution of urea+Mo, (4) urea+Mo+BA (benzyladenine BA), (5) urea $+\mathrm{Mo}+\mathrm{BA}+$ sucrose, (6) BA in the concentration of $5 \mathrm{mg} \cdot \mathrm{dm}^{-3}$ and (7) BA in the concentration of $10 \mathrm{mg} \cdot \mathrm{dm}^{-3}$. In combinations $2-5$ the following concentrations of components in solutions were applied: urea and sucrose each in $20 \mathrm{~g} \cdot \mathrm{dm}^{-3}$, molybdenum $1 \mathrm{mg} \cdot \mathrm{dm}^{-3}$, benzyladenine $5 \mathrm{mg} \cdot \mathrm{dm}^{-3}$. Foliar nutrition was applied three times. In both years of study the greatest mass of storage roots and whole plant (haulm + root) was determined after spraying with benzyladenine in $5 \mathrm{mg} \cdot \mathrm{dm}^{-3}$ concentration. Plants with urea $+\mathrm{Mo}+\mathrm{BA}+$ sucrose foliar nutrition were characterized by a comparable mass of roots and whole plant but only in 2005. In both years of study plants treated with urea only had the lowest root mass and the highest content of phenolic compounds and the lowest (in 2004 and the means from 2004-2005) content of soluble sugars in roots. Foliar nutrition with urea+Mo+BA+sucrose and spraying with benzyladenine exclusively in both applied concentrations caused a significant increase in the content of sugars (in 2004 and the means from 2004-2005) as well as carotenoids (except for combination no. 7 - in 2005 and the means from 2004$2005)$ in storage roots.

key words: carrot, foliar nutrition, sugars, phenols, molybdenum, sucrose, benzyladenine

INTRODUCTION

After performing the foliar nutrition with solution of nutritional components, nitrogen in urea form is

Corresponding author:

e-mail: ssmolen@ogr.ar.krakow.pl; wjsady@ogr.ar.krakow.pl

(C) Copyright by RIVC 
a nutrient of the fastest leaf uptake. Additionally, urea causes hydration of cuticle what facilitates assimilation 

of urea itself and other nutritional components by this layer (Marschner 1995, Michałojć \& Szewczuk 2003). The amide nitrogen from urea is not directly incorporated into the metabolic path of this element in plant. The ammonium nitrogen, being the result of urea hydrolysis by the urease enzyme, is incorporated into simple organic compounds (Marschner 1995). Ammonium nitrogen assimilation takes place in GS-GOGAT cycle which occurs in chloroplasts. The crucial role in nitrogen assimilation process plays the alpha-oxoglutarate (created in the Krebs cycle) which is transformed by GDH to glutamine, which in turn takes part in GSGOGAT cycle (Tischner 2000, Masclaux-Daubresse et al. 2002). Thus, the efficiency of the nitrogen assimilation process will be better at higher degrees of photo-synthetic productivity (Masclaux-Daubresse et al. 2002).

As reported by Marschner (1995) compounds with small molecule mass e.g. sugars (sucrose) do not penetrate through cuticular layer and their assimilation takes place in the cuticular pores. Sucrose is transported between parenchymal cells of leaf with the participation of transporter proteins on the basis of sucrose $/ \mathrm{H}^{+}$symport (Roshani \& Arnd 1998, Starck 2003). The endogenous sucrose created in the process of photosynthesis in parenchymal cells as well as the exogenous sucrose (from foliar nutrition) are then transported by phloem to assimilate acceptors, such as: young developing leaves or storage roots (Starck 2003).

Starck (2003) informs that sugar also plays the role of signal substances undirectly informing cells or individual structures about the level of supply and demand for the photosynthesis products. Sugars together with hormones participate in the transduction of signals on the level of gene expression. Research done by Kováčik (1999) demonstrated that foliar nutrition of radish with $5 \%$ sucrose solution applied 12 days before harvesting caused an increase in yield level as well as a decrease in nitrate content in storage organs of this plant. Reduction of nitrate content was obtained after spraying plants with an extract derived from Lupinus angustifolius seeds (Cwojdziński et al. 1996, Barczak \& Cwojdziński 1998). According to Cwojdziński et al. (1996) this extract, apart from nutriational components, proteins and sugar, most probably contained dihydrozeatine (cytokinin). Another fitohormone of cytokinin group is benzyladenine (BA). The physiological role of cytokinins is, apart from the others, connected with regulation of biochemical processes by controlling enzyme activity (Borkowska 1997). Exogenous cytokinins caused an uprising content of alpha-linolenic acid (ALA - direct precursor of chlorophyll) in leaves (Yaronskaya et al. 2006). These compounds were found to regulate the nitrate reductase activity (Yu et al. 1998) which also depends on the presence of molybdenum as a cofactor or on assimilative potential of plants (Campbell 1999).

This research aimed at determining the effect of foliar nutrition with urea, molybdenum, sucrose and benzyladenine on carrot plants yield and the content of soluble sugars, carotenoids and phenolic compounds in carrot storage roots. 


\section{MATERIAL AND METHODS}

In years 2004-2005 carrot Kazan $F_{1}$ was cultivated in $60 \times 40 \times 20 \mathrm{~cm}$ in open-work containers, placed in the open field under a shade providing fabric. The containers were filled in with medium silt loam (35\% sand, $28 \%$ silt and $37 \%$ loam) with mean content of organic substance $3.25 \%$ and the following contents of the available nutrient forms soluble in 0.03 $\mathrm{M}$ acetic acid: $\mathrm{N}\left(\mathrm{N}-\mathrm{NO}_{3}+\mathrm{N}-\mathrm{NH}_{4}\right)$ 28.0, P 4.3, $\mathrm{K}$ 28.8, $\mathrm{Mg} 137.4$ and $\mathrm{Ca}$ $1424.7 \mathrm{mg} \cdot \mathrm{dm}^{-3}$ of soil. The total sorption capacity of the soil used for the experiment was $11.2 \mathrm{cmol}^{+} \cdot \mathrm{kg}^{-1}$ at $89.8 \%$ base saturation ratio. The soil reaction $\mathrm{pH}_{\mathrm{H}_{2} \mathrm{O}}$ was 7.29 while total salt content (EC) was on the level of $0.45 \mathrm{mS} \cdot \mathrm{cm}^{-1}$.

The sowing was performed on $20^{\text {th }}$ April 2004 and $27^{\text {th }}$ April 2005. The content of the available nutrient forms during vegetation period was maintained on the following levels: $\mathrm{P}$ 80, K 120, Mg 80, Ca $2000 \mathrm{mg} \cdot \mathrm{dm}^{-3}$ of soil by means of fertilization (based on the results of the soil chemical analysis) conducted on $8^{\text {th }}$ April and $5^{\text {th }}$ July 2004 and on $25^{\text {th }}$ April and $1^{\text {st }}$ July 2005. Nutrients were supplied to the soil in $\mathrm{KH}_{2} \mathrm{PO}_{4}, \mathrm{~K}_{2} \mathrm{SO}_{4}, \mathrm{CaCO}_{3}$ and $\mathrm{MgSO}_{4} \cdot 7 \quad \mathrm{H}_{2} \mathrm{O}$ with microelements (contained: $0.35 \% \mathrm{Mn}, 0.3 \% \mathrm{Cu}, 0.2 \%$ $\mathrm{Zn}, 0.05 \% \mathrm{~B}$ and $0.01 \% \mathrm{Mo}$ ).

The soil fertilization with nitrogen was applied three times during cultivation period (on $20^{\text {th }}$ April, $5^{\text {th }}$ July and $23^{\text {rd }}$ August, 2004 and on $25^{\text {th }}$ April, $1^{\text {st }}$ July and $22^{\text {nd }}$ August 2005) to supplement the N-mineral content to the level of $100 \mathrm{mg} \mathrm{N} \cdot \mathrm{dm}^{-3}$ of soil basing on the results of the soil chemical analysis.
The following combinations of experiments were arranged: (1) control - without foliar nutrition, and foliar nutrition with: (2) urea, (3) solution of urea+Mo, (4) urea+Mo+BA (benzyladenine $\mathrm{BA}$ ), (5) urea $+\mathrm{Mo}+$ $\mathrm{BA}+$ sucrose, (6) BA in the concentration of $5 \mathrm{mg} \cdot \mathrm{dm}^{-3}$ and (7) BA in the concentration of $10 \mathrm{mg} \cdot \mathrm{dm}^{-3}$. In combinations 2-5, following concentrations of components in solution were applied: urea and sucrose each in $20 \mathrm{mg} \cdot \mathrm{dm}^{-3}$, molybdenum $1 \mathrm{mg} \cdot \mathrm{dm}^{-3}$, benzyladenine $5 \mathrm{mg} \cdot \mathrm{dm}^{-3}$. In individual sites of the experiment plants were sprayed three times $\left(30^{\text {th }}\right.$ June, $6^{\text {th }}$ August and $24^{\text {th }}$ August 2004 and $28^{\text {th }}$ June, $1^{\text {st }}$ August and $23^{\text {rd }}$ August 2005). Each experimental treatment was randomized in three replications which consisted of thirty carrot plants per one container.

The carrot harvesting and yield evaluation were performed on $15^{\text {th }}$ September, 2004 and $27^{\text {th }}$ September 2005; soil samples for analysis were collected at the same time.

The analyses of plant material were performed immediately after harvesting in the fresh plant material. In carrot storage roots the total content of carotenoid compounds was assessed by acetone and n-hexane extraction according to PN-90/A75101.12, the phenolic compounds content was determined with the use of Folin and Ciocalteu reagent (Swain \& Hillis 1959), and the amount of soluble sugars was determined by the anthrone method (Yemm \& Wills 1954).

The soil reaction $\mathrm{pH}_{\mathrm{H}_{2} \mathrm{O}}$ was assessed by potentiometer; total salt concentrations in soil (EC) was measured conductometrically and the con- 
tent of $\mathrm{N}-\mathrm{NH}_{4}, \mathrm{~N}^{-\mathrm{NO}_{3}}, \mathrm{P}, \mathrm{K}, \mathrm{Mg}, \mathrm{Ca}$ after extraction $0.03 \mathrm{M}$ of acetic acid (Nowosielski 1988). The nitrogen was estimated by the micro-distillation method according to Bemner in Starck modification; $\mathrm{K}, \mathrm{Mg}, \mathrm{Ca}$ was analysed by the AAS method, and P by the vanadium-molybdenum method (Ostrowska et al. 1991).

All results were statistically verified by ANOVA module of Statistica 7.1 PL programme for significance level $\mathrm{P}<0.05$. Changes of any signifycance were assessed with the use of variance analysis. The value of LSD (least significant difference) was calculated with Duncan test.

Climate conditions during the experimental period are presented in Table 1. Year 2005 was characterized by higher average air temperature in May, July and September, and the lowest temperature in August in comparison with 2004. In both years of the experiment the average air temperature in June was similar. 2005 was marked with a slightly higher amount of rainfall in May, July and August with a lower amount in June and September, than in 2004. A relatively high monthly amount of sunshine hours in May, June and July was measured in 2005 and in August
2004. However, September in both years of the experiment was distinguished with a similar amount of sunshine hours. Generally, during the carrot cultivation period, the year 2005 was characterized by a higher amount of rainfall and sunshine hours than 2004.

\section{RESULTS}

Foliar nutrition treatments applied in this experiment had a signifycant influence on carrot yield (Table 2). In both years of studies plants sprayed with BA only in $5 \mathrm{mg} \cdot \mathrm{dm}^{-3}$ solution (combination no.6) revealed greater mass of storage roots and whole plant (haulm + root) as well as leaves - means from 2004 and 2005. A comparable mean root weight was found in plants sprayed with BA in 10 $\mathrm{mg} \cdot \mathrm{dm}^{-3}$ concentration (combination no.7 - in 2004) as well as in those fertilized foliarly with the solution of urea, molybdenum, BA and sucrose (combination no.5 - in 2005 and means from 2004 and 2005). In both years of studies the lowest yield of roots and the whole plant (and mass of haulm - means from 2004 and 2005) was found in plants fertilized with urea only.

Table 1. Meteorological data for the experiments region (Kraków-Balice)

\begin{tabular}{ccccccc}
\hline & \multicolumn{3}{c}{ Year 2004 } & \multicolumn{3}{c}{ Year 2005 } \\
\cline { 2 - 7 } Month & $\begin{array}{c}\text { Average air } \\
\text { temperature } \\
\left({ }^{\circ} \mathrm{C}\right)\end{array}$ & $\begin{array}{c}\text { Rainfall } \\
(\mathrm{mm})\end{array}$ & $\begin{array}{c}\text { Sunshine } \\
(\mathrm{h})\end{array}$ & $\begin{array}{c}\text { Average air } \\
\text { temperature } \\
\left({ }^{\circ} \mathrm{C}\right)\end{array}$ & $\begin{array}{c}\text { Rainfall } \\
(\mathrm{mm})\end{array}$ & $\begin{array}{c}\text { Sunshine } \\
(\mathrm{h})\end{array}$ \\
\hline May & 12.7 & 42.6 & 193.7 & 14.5 & 61.3 & 241.5 \\
June & 16.8 & 56.4 & 180.1 & 17.0 & 40.6 & 249.3 \\
July & 18.4 & 97.4 & 200.9 & 19.9 & 134.4 & 220.4 \\
August & 18.7 & 77.2 & 229.0 & 17.3 & 102.6 & 182.3 \\
September & 13.3 & 36.1 & 188.3 & 14.0 & 27.2 & 190.9 \\
\hline Mean & 16.0 & 61.9 & 198.4 & 16.5 & 73.2 & 216.9 \\
Sum & - & 309.7 & 992.0 & - & 366.1 & 1084.4 \\
\hline
\end{tabular}




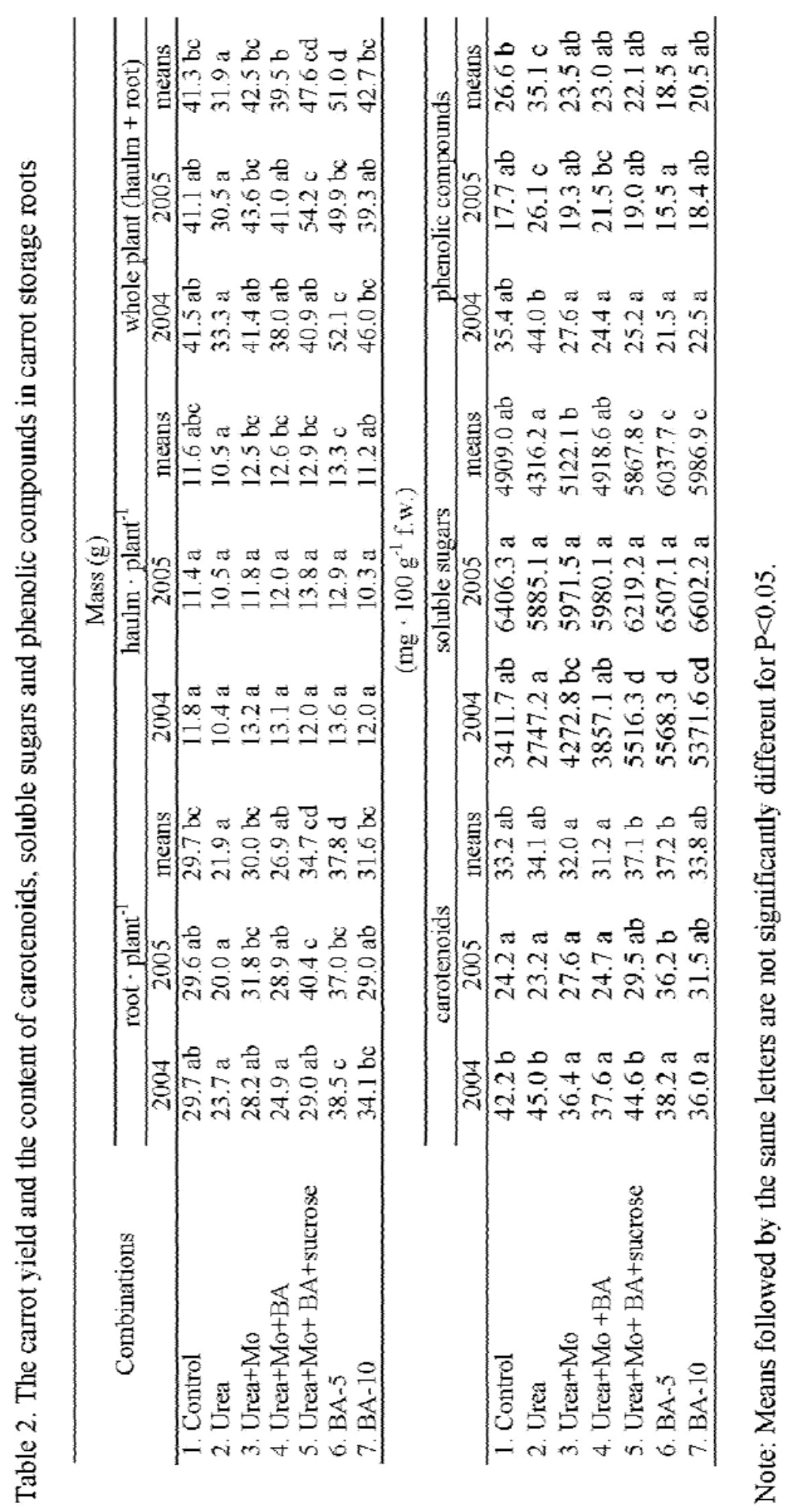


The foliar nutrition treatment significantly affected the content of carotenoids, soluble sugars and phenolic compounds in carrot (Table 2).

When compared to other treatments, spraying plants with BA only in $5 \mathrm{mg} \cdot \mathrm{dm}^{-3}$ concentration (combination no. 6 - in 2005 and means from 2004 and 2005) as well as foliar nutrition with the mixture of urea, molybdenum, BA and sucrose (combination no. 5 - in both years of studies) caused an increase in carotenoid con- centration in carrot. The results from 2004 and means from 2004 and 2005 showed that storage roots of plants from combinations no 5, 6 and 7 contained the highest level of soluble sugars, while storage roots of plants nourished foliarly with urea only were characterized by the lowest content of sugars. However, in both years of studies plants treated with urea only had the highest content of phenolic compounds.

Table 3. Chemical properties of the soil after carrot harvesting in 2004 and 2005

\begin{tabular}{|c|c|c|c|c|c|c|c|}
\hline \multirow{2}{*}{ Combinations } & \multirow{2}{*}{$\mathrm{pH}_{\mathrm{H}_{2} \mathrm{O}}$} & \multirow{2}{*}{$\begin{array}{c}\mathrm{EC} \\
\left(\mathrm{mS} \cdot \mathrm{cm}^{-1}\right)\end{array}$} & \multicolumn{5}{|c|}{$\left(\mathrm{mg} \cdot \mathrm{dm}^{-3}\right.$ soil $)$} \\
\hline & & & $\mathrm{N}^{1}$ & $\mathrm{P}$ & $\mathrm{K}$ & $\mathrm{Mg}$ & $\mathrm{Ca}$ \\
\hline & \multicolumn{7}{|c|}{2004} \\
\hline 1. Control & $6.92 \mathrm{~b}$ & $0.77 \mathrm{ab}$ & $101.5 \mathrm{~cd}$ & $87.3 \mathrm{~d}$ & $27.8 \mathrm{c}$ & $137.0 \mathrm{abcd}$ & $2347.3 \mathrm{a}$ \\
\hline 2. Urea & $6.89 \mathrm{~b}$ & $0.82 \mathrm{ab}$ & $122.5 \mathrm{~d}$ & $65.1 \mathrm{ab}$ & $14.3 \mathrm{a}$ & $146.9 \mathrm{~d}$ & $2278.3 a$ \\
\hline 3. Urea+Mo & $6.89 \mathrm{~b}$ & $0.93 \mathrm{~b}$ & $115.5 \mathrm{~d}$ & $60.6 \mathrm{a}$ & $14.7 \mathrm{a}$ & $135.3 \mathrm{abc}$ & $2367.6 \mathrm{a}$ \\
\hline 4. Urea+Mo+BA & $6.92 \mathrm{~b}$ & $0.76 \mathrm{ab}$ & $82.3 \mathrm{bc}$ & $85.2 \mathrm{~cd}$ & $24.1 \mathrm{bc}$ & $142.9 \mathrm{~cd}$ & $2123.6 \mathrm{a}$ \\
\hline 5. Urea $+\mathrm{Mo}+\mathrm{BA}+$ sucr. & $6.79 \mathrm{a}$ & $1.10 \mathrm{c}$ & $75.3 \mathrm{bc}$ & $84.3 \mathrm{~cd}$ & $22.9 \mathrm{~b}$ & $140.5 \mathrm{bcd}$ & $2090.9 \mathrm{a}$ \\
\hline 6. BA-5 & $7.09 \mathrm{c}$ & $0.65 \mathrm{a}$ & $42.0 \mathrm{a}$ & $68.9 \mathrm{~b}$ & $14.3 \mathrm{a}$ & $130.9 \mathrm{ab}$ & $2151.3 \mathrm{a}$ \\
\hline \multirow[t]{2}{*}{ 7. BA-10 } & $6.95 \mathrm{~b}$ & $0.67 \mathrm{a}$ & $57.8 \mathrm{ab}$ & $80.3 \mathrm{c}$ & $27.9 \mathrm{c}$ & $127.8 \mathrm{a}$ & $2113.4 \mathrm{a}$ \\
\hline & \multicolumn{7}{|c|}{2005} \\
\hline 1. Control & $5.91 \mathrm{a}$ & $0.12 \mathrm{a}$ & $28.0 \mathrm{ab}$ & $86.2 \mathrm{ab}$ & $16.5 a b$ & $181.5 \mathrm{a}$ & $1299.9 \mathrm{a}$ \\
\hline 2. Urea & $6.03 \mathrm{~b}$ & $0.25 \mathrm{c}$ & $66.5 \mathrm{c}$ & $80.8 \mathrm{a}$ & $15.8 \mathrm{a}$ & $188.8 \mathrm{a}$ & $1467.0 \mathrm{a}$ \\
\hline 3. Urea + Mo & $5.87 \mathrm{a}$ & $0.17 \mathrm{~b}$ & $49.0 \mathrm{abc}$ & $87.4 \mathrm{abc}$ & $20.4 \mathrm{bc}$ & $162.9 \mathrm{a}$ & $1238.7 \mathrm{a}$ \\
\hline 4. Urea+Mo+BA & $6.09 \mathrm{~b}$ & $0.16 \mathrm{ab}$ & $59.5 \mathrm{bc}$ & $91.0 \mathrm{abcd}$ & $14.5 \mathrm{a}$ & $176.9 \mathrm{a}$ & $1515.2 \mathrm{a}$ \\
\hline 5. Urea $+\mathrm{Mo}+\mathrm{BA}+$ sucr. & $5.84 \mathrm{a}$ & $0.16 \mathrm{ab}$ & $36.7 \mathrm{abc}$ & $100.2 \mathrm{~d}$ & $17.9 \mathrm{ab}$ & $186.1 \mathrm{a}$ & $1396.4 \mathrm{a}$ \\
\hline 6. BA-5 & $6.20 \mathrm{c}$ & $0.19 \mathrm{~b}$ & $19.2 \mathrm{a}$ & $94.0 \mathrm{bcd}$ & $16.6 \mathrm{ab}$ & $192.0 \mathrm{a}$ & $1413.1 \mathrm{a}$ \\
\hline \multirow[t]{2}{*}{ 7. BA-10 } & $6.08 \mathrm{~b}$ & $0.12 \mathrm{a}$ & $19.2 \mathrm{a}$ & $97.8 \mathrm{~cd}$ & $22.8 \mathrm{c}$ & $182.6 \mathrm{a}$ & $1379.8 \mathrm{a}$ \\
\hline & \multicolumn{7}{|c|}{ Means from 2004-2005 } \\
\hline 1. Control & $6.42 \mathrm{bc}$ & $0.45 \mathrm{a}$ & $64.8 \mathrm{~cd}$ & $86.8 \mathrm{bc}$ & $22.2 \mathrm{~d}$ & $159.3 \mathrm{a}$ & $1823.6 \mathrm{a}$ \\
\hline 2. Urea & $6.46 \mathrm{c}$ & $0.54 \mathrm{bc}$ & $94.5 \mathrm{e}$ & $73.0 \mathrm{a}$ & $15.1 \mathrm{a}$ & $167.9 \mathrm{a}$ & $1872.7 \mathrm{a}$ \\
\hline 3. Urea+Mo & $6.38 \mathrm{~b}$ & $0.55 \mathrm{c}$ & 82.3 de & $74.0 \mathrm{a}$ & $17.6 \mathrm{ab}$ & $149.1 \mathrm{a}$ & $1803.2 \mathrm{a}$ \\
\hline 4. Urea+Mo+BA & $6.51 \mathrm{~d}$ & $0.46 \mathrm{ab}$ & $70.9 \mathrm{~cd}$ & $88.1 \mathrm{~cd}$ & $19.3 \mathrm{bc}$ & $159.9 \mathrm{a}$ & $1819.4 \mathrm{a}$ \\
\hline 5. Urea+Mo+BA+sucr. & $6.32 \mathrm{a}$ & $0.63 \mathrm{~d}$ & $56.0 \mathrm{bc}$ & $92.3 \mathrm{~d}$ & $20.4 \mathrm{~cd}$ & $163.3 \mathrm{a}$ & $1743.7 \mathrm{a}$ \\
\hline 6. BA-5 & $6.65 \mathrm{e}$ & $0.42 \mathrm{a}$ & $30.6 \mathrm{a}$ & $81.5 \mathrm{~b}$ & $15.5 \mathrm{a}$ & $161.5 \mathrm{a}$ & $1782.2 \mathrm{a}$ \\
\hline 7. BA-10 & $6.52 \mathrm{~d}$ & $0.40 \mathrm{a}$ & $38.5 \mathrm{ab}$ & $89.1 \mathrm{~cd}$ & $25.4 \mathrm{e}$ & $155.2 \mathrm{a}$ & $1746.6 \mathrm{a}$ \\
\hline
\end{tabular}

Note: see Table 2, ${ }^{1}-\mathrm{N}-\mathrm{NO}_{3}+\mathrm{N}-\mathrm{NH}_{4}$ 
In both years of studies there were found significant variations in chemical properties of soil after the cultivation of carrot, which included: $\mathrm{pH}$, the total content of salt (EC) and concentration of N-mineral (N$\mathrm{NO}_{3}+\mathrm{N}-\mathrm{NH}_{4}$ ), phosphorus and potassium as well as magnesium in 2004 (Table 3). Soil samples from all experiment combinations were characterized by a comparable level of available forms of calcium - and magnesium in 2005 and means from 2004 and 2005. Taking into account the absolute value of numbers, one should conclude that the most significant variations were observed in mineral nitrogen content. In both years of studies the lowest level of both nitrogen forms in soil $\left(\mathrm{N}-\mathrm{NO}_{3}+\mathrm{N}-\mathrm{NH}_{4}\right)$ was determined after cultivation of plants sprayed with BA only (combinations no. 6 and 7), with the highest one noted after cultivation of plants nourished with urea only (combination no.2).

\section{DISCUSSION}

The research by Jeannette et al. (2000) performed in vitro on corn leaves demonstrated that sucrose in $5 \%$ concentration caused a reduction in translation of $r b c S$ gene coding of smaller subunit of Rubisco responseble for $\mathrm{CO}_{2}$ incorporation in CalvinBenson process. Moreover, Furbank et al. (1997) showed that 5\% sucrose content in nutrient medium caused an increase in chlorophyll content by $20 \%$ on leaf surface unit and an increased net photosynthetic activity in tobacco leaves. Thus, the application of exogenous sucrose depending on the plant cultivars (type $\mathrm{C}_{3}$ or $\mathrm{C}_{4}$ ) and growth conditions can result in weak- ening or strengthening of assimilative potential of plants, which in turn can cause a decrease or an increase of yield quantity. Kováčik (1999) demonstrated that foliar nutrition of radish with $5 \%$ solution of sucrose applied 12 days before harvesting increased yield quantity of roots but decreased yield of leaves in plants fertilized with 120 and $160 \mathrm{~kg} \mathrm{~N} \cdot \mathrm{ha}^{-1}$.

In our research, variable climatic conditions in both years of studies (i.e higher average air temperature in May, July and September and higher amount of rainfall and greater amount of sunshine hours in 2005 compared with 2004), specifically modified the effect of foliar nutrition on the yield of carrot plants and on the content of carotenoids and soluble sugars, but had no significant effect on the level of phenolic compounds in carrot. The triple foliar nutrition of plants with solution containing sucrose, urea, Mo and BA caused an increase in storage roots and whole plant (haulm + root) mass in carrot but only in 2005. Despite of variable climatic conditions during cultivation, in both years of studies the highest level of yield storage roots was noted in plants sprayed with BA in $5 \mathrm{mg} \cdot \mathrm{dm}^{-3}$ concentration. This observation may be linked with the cytokinin effect on cell division stimulation (Borkowska 1997). Yaronskaya et al. (2006) showed that kinetin (another fitohormone from cytokinin group) increased the content of alpha-linolenic acid (ALA - direct precursor of chlorophyll) and $\mathrm{CO}_{2}$ intake by barley seedlings. It can be therefore assumed that in our research BA (in $5 \mathrm{mg} \cdot \mathrm{dm}^{-3}$ concentration) could have caused a periodical growth in assimilative potential of plants, which 
in turn, resulted in the increase of storage roots mass and higher content of carotenoids (in 2005 and means from 2004 and 2005) and soluble sugars (in 2004 and means from 2004 and 2005). Yet, no significant influence of foliar nutrition on the content of assimilation pigments in carrot leaves was revealed in our experiment (Smoleń et al. 2009). It should be emphasized that a comparable storage roots yield as well as the content of carotenoids and soluble sugars were observed in case of foliar nutrition with the combination of urea, Mo, BA and sucrose - means from 2004 and 2005.

The decrease of root mass in plants nourished with urea only (found in both years of study) is quite difficult to interpret as generally the majority of research results demonstrates the growth of plant yield after foliar treatment. For example, additional spraying plants with urea resulted in higher yield of carrot (Rożek et al. 2000). Also Sady et al. (2005) in field experiments presented a favourable effect of foliar nutrition with urea and Supervit-R on the carrot root biomass, independently from the dose of nitrogen fertilizer. On the other hand, foliar nutrition with multicomponent fertilizers can cause a decrease in yield quantity in some variations, what was demonstrated in potato, parsley and cucumber plants (Jaskulski 2005).

Foliar nutrition, particularly with a reduced nitrogen form, may cause a decrease in reaction of leaf cell apoplast. Such a correlation was revealed by Mühling and Läuchli (2001) by the nutrition of sunflower plants with ammonium sulphate. Study by Ri- cardo and Sovia (1974) and information presented by Starck (2003) show that the decline in cell juice reaction may lead to higher activity of acid invertase hydrolising sucrose into glucose and fructose. These simple sugars are then used in the respiration cycle and other metabolic pathways resulting in synthesis of plant seconddary metabolits. In both years of studies our research revealed slight and statistically insignificant reduction in the content of soluble sugars in storage roots of plants nourished foliarly with urea only. This observation confirms to some extent findings of Ricardo and Sovia (1974) and Starck (2003). Results of our experiments from 2004 suggest that foliar nutrition with urea in combination with Mo, BA and sucrose (combinations no. 3, 4 and 5) can diminish the unfavourable effect of urea on sugars content in carrot. The fact that in 2004 roots of plant treated with foliar nutrition with urea, Mo and BA combination (combination no. 4) contained the same amount of sugars as control plants but less than plants additionally nourished with sucrose (combination no.5), points to a positive effect of sucrose on the soluble sugar concentration in storage roots. The fact that these correlations were noted only in 2004 may have resulted from weather conditions, which were characterized by lower average air temperature in May, July and September as well as lower amount of rainfall and sunshine hours compared with 2005.

Despite variable climatic conditions in both years of our study, an increase in the content of phenolic compounds in storage roots of carrot plants nourished foliarly with urea 
was observed. The experiments conducted by Rożek et al. (2000) demonstrated that foliar nutrition with urea applied to plants unfertilized to soil and to those fertilized with full nitrogen dose resulted in an increasing level of phenolic compounds in carrot, which was not noted in case of plants fertilized with only half a dose of this element. Therefore, it seems that the effect of foliar nutrition with urea on the concentration of phenolic compounds in carrot can be linked with the mineral nitrogen content in soil. Our results (at the end of plant cultivation period) revealed the highest content of mineral nitrogen in soil where plants nourished foliarly with urea only were cultivated. The lowest content of this element was determined in soil after cultivation of plants sprayed with BA (in both concentrations), which could be caused by a greater plant intake of this element from the soil in these combinations (Smoleń et al. 2009). This can also explain the lack of effect, or even the noted tendency (though statistically insignificant) to lower the content of phenolic compounds in carrot storage roots after the application of BA only as well as after conjoint application of this fitohormone with urea, molybdenum and sucrose.

\section{CONCLUSIONS}

The presented research results demonstrated an influence of variable climatic conditions in both years of study on the effect of foliar nutrition with urea, benzyladenine, sucrose and molybdenum on carrot plants yield and the content of soluble sugars and carotenoids, but not on the content of phenolic compounds in carrot storage roots. Spraying plants with BA exclusively in $5 \mathrm{mg} \cdot \mathrm{dm}^{-3}$ solution (combination no. 6) as well as foliar nutrition with the mixture of urea, molybdenum, BA and sucrose (combination no. 5) are the most favourable combinations resulting in a simultaneous increase in roots mass and, to some small extent, the content of carotenoids and soluble sugars in carrot storage roots. The roots of these plants treated with urea only were characterized by the highest content of phenolic compounds. The use of benzyladenine only has a different influence on the content of carotenoids and soluble sugars in carrot in comparison to its conjoint application with urea and molybdenum and urea, molybdenum and sucrose.

\section{REFERENCES}

Barczak B., Cwojdziński W. 1998. [Content of macroelements in cucumber fruits sprayed with pesticides and the lupine extract.] Scientific Papers of the Agriculture University of Poznań 27: 11-18. [in Polish with English summary]

Borkowska B. 1997. Cytokiny. pp: 60-71. In: Regulatory wzrostu i rozwoju roślin. Właściwości i działanie. (S. Jankiewicz ed.). Wyd. Nauk. PWN, Warszawa. [in Polish]

Campbell W.H. 1999. Nitrate reductase structure, function and regulation: Bridging the gap between biochemistry and physiology. Annual Review of Plant Physiology and Plant Molecular Biology 50: 277-303. [DOI: 10.1146/annurev.arplant.50.1.277]

Cwojdziński W., Barczak B., Polocyn J. 1996. [The effect of lupine extract on the decrease of nitrate nitrogen in selected vegetables.] Zesz. Probl. Post. Nauk Roln. 440: 45-50. [in Polish with English summary] 
Furbank R.T., Pritchard J., Jenkins C.L.D. 1997. Effects of exogenous sucrose feeding on photosynthesis in the $\mathrm{C} 3$ plant tobacco and C4 plant Flaveria bidentis. Australian Journal of Plant Physiology 24: 291-299.

Jaskulski D. 2005. [Production - and cost - effectives of foliar application of Sonata fertilizers in the cultivation of some filed - grown vegetables.] Fragmenta Agronomica 22: 419428. [in Polish with English summary]

Jeannette E., Reyss A., Grégory N., Gantet P., Prioul J.L. 2000. Carbohydrate metabolism in a heatgirdled maize source leaf. Plant, Cell \& Environment 23: 61-69. [DOI: 10.1046/j.1365-3040.2000. 00519.x]

Kováčik P. 1999. [Effect of nitrogenous nutrition and sacharose foliar application on yield parameters of radish.] Zahradnictví Hort Scien (Prague) 26: 97-102. [in Czech with English summary]

Marschner H. 1995. Mineral nutrition of higher plants. Second edition. Academic Press, London, England.

Masclaux-Daubresse C., Valadier M.H., Carrayol E., Reisdorf-Cren M., Hirel B. 2002. Diurnal changes in the expression of glutamate dehydrogenase and nitrate reductase are involved in the $\mathrm{C} / \mathrm{N}$ balance of tobacco leaves. Plant Cell Environment 25: 1451-1462.

Michałojć Z., Szewczuk C. 2003. [Theoretical aspects of foliar nutrition.] Acta Agrophysica 85: 9-17. [in Polish with English summary]

Mühling K.H., Läuchli A. 2001. Influence of chemical form and concentration of nitrogen on apoplastic $\mathrm{pH}$ of leaves. Journal Plant Nutrition 24: 399-411.

Nowosielski O. 1988. Zasady opracowywania zaleceń nawozowych w ogrodnictwie. PWRiL Warszawa. [in Polish]
Ostrowska A., Gawaliński S., Szczubiałkowska Z. 1991. Metody analiz i oceny właściwości gleb i podłoży katalog. Instytut Ochrony Środowiska. Warsaw. [in Polish]

Ricardo C.P.P., Sovia D. 1974. Development of tuberous roots and sugar accumulation as related to invertase activity and mineral nutrition. Planta 118: 43-55.

Roshani S., Arnd S. 1998. Characterization of Source- and Sink-Specific Sucrose $/ \mathrm{H}^{+}$Symporters from Carrot. Plant Physiology 118: 1473-1480.

Rożek S., Sady W., Kasprzyk A. 2000. Wpływ pozakorzeniowego dokarmiania roślin na wielkość i jakość plonu marchwi. Zesz. Nauk. AR Krak. 364, 71: 159-162. [in Polish]

Sady W., Smoleń S., Rożek S. 2005. Effect of differentiated nitrogen fertilization and foliar application on yield and biological quality of carrot crop. Horticulture and Vegetable Growing 24: 273-281.

Smoleń S., Sady W., Wojciechowska R. 2010. The effect of foliar nutrition with nitrogen, molybdenum, sucrose and benzyladenine on the nitrogen management in carrot. Veget. Crops Res. Bull. 72: 83-92.

Starck Z. 2003. Transport i dystrybucja substancji pokarmowych w roślinach. Wyd. SGGW, Warszawa. [in Polish]

Swain T., Hillis W.E. 1959. Phenolic constituents of Prunus domestica. I. Quantitative analysis of phenolic constituents. Journal of the Science and Food Agricultural 10: 63-71.

Tischner R. 2000. Nitrate uptake and reduction in higher and lower plants. Plant Cell Environment 23: 1005 1024.

Yaronskaya E., Vershilovskaya I., Poers Y., Alawady A.E., Averina N., Grimm B. 2006. Cytokinin effects on tetrapyrrole biosynthesis and photosynthetic activity in barley seedlings. Planta 224: 700-709. 
Yemm E.W., Wills A.J. 1954. The estimation of carbohydrates in plant extracts by antrone. Biochemistry Journal 57: 508-514.

Yu X., Sukumaran S., Márton L. 1998. Differential expression of the
Arabidopsis Nial and Nia2 genes. Cytokinin-Induced nitrate reductase activity is correlated with increased Nial transcription and mRNA levels. Plant Physology 16: 1091-1096.

\section{WPŁYW ODŻYWIANIA DOLISTNEGO MOCZNIKIEM, MOLIBDENEM, SACHAROZA I BENZYLOADENINA NA PLON ORAZ ZAWARTOŚĆ NIEKTÓRYCH ZWIAZKÓW ORGANICZNYCH W KORZENIACH SPICHRZOWYCH MARCHWI}

\section{Streszczenie}

Marchew Kazan $\mathrm{F}_{1}$ uprawiano w latach 2004-2005 w pojemnikach ażurowych o wymiarach $60 \times 40 \times 20 \mathrm{~cm}$ wypełnionych gliną średnią pylastą, umieszczonych na terenie otwartym pod cieniówka. W badaniach wyróżniono następujące kombinacje: (1) kontrola - bez dokarmiania dolistnego, oraz dokarmianie dolistne: (2) mocznikiem, (3) roztworem mocznik $+\mathrm{Mo}$, (4) mocznik+Mo+BA (benzylodenina - skrót BA), (5) mocznik+Mo+BA+sacharoza, (6) BA w stężeniu $5 \mathrm{mg} \cdot \mathrm{dm}^{-3}$ i (7) BA w stężeniu $10 \mathrm{mg} \cdot \mathrm{dm}^{-3}$. W roztworach z kombinacji 2-5 zastosowano następujące stężenia składników: mocznik i sacharoza po $20 \mathrm{~g} \cdot \mathrm{dm}^{-3}$, molibden $1 \mathrm{mg} \cdot \mathrm{dm}^{-3}$, benzyloadenina $5 \mathrm{mg} \cdot \mathrm{dm}^{-3}$. Odżywianie dolistne wykonywano trzykrotnie. W obydwu latach badań zwiększenie masy korzeni spichrzowych oraz całej rośliny (nać + korzeń) stwierdzono po opryskiwaniu roślin benzyloadeniną w stężeniu $5 \mathrm{mg} \cdot \mathrm{dm}^{-3}$. Porównywalną masą korzeni jak i całej rośliny, ale tylko w 2005 roku charakteryzowały się rośliny odżywiane mocznikiem+Mo+BA +sacharozą. W obydwu latach badań rośliny odżywiane dolistnie samym mocznikiem charakteryzowały się najniższą masą korzeni oraz najwyższą zawartością związków fenolowych i najniższą (w 2004 roku oraz średnie z lat 2004-2005) zawartością cukrów rozpuszczalnych w korzeniach. Odżywianie dolistne mocznikiem $+\mathrm{Mo}+\mathrm{BA}+$ sacharoza oraz opryskiwanie samą benzyloadeniną $\mathrm{w}$ obydwu stężeniach powodowało istotne podwyższenie zawartości cukrów (w 2004 roku oraz średnie z lat 2004-2005), jak również karotenoidów (w 2005 roku oraz średnie z lat 2004-2005 - za wyjątkiem kombinacji nr 7) w korzeniach spichrzowych. 